\title{
Unanswered Questions in Audience Research
}

\author{
David Morley ${ }^{1}$ \\ Universidade de Londres
}

\begin{abstract}
As its title implies, this article explores a number of unanswered questions and outstanding issues in contemporary audience research. These include: models of the "active audience"; questions of cultural power; global media and transnational audiences; methodologies in audience research; problems of essentialism in the conceptualization of categories of audience members; the strengths and limitations of the encoding/decoding model; models of intellectual progress in the field; the new media and technologies of "newness." My title is derived from Bertolt Brecht's "Anecdotes of Mr Keuner" in which he extols the virtue of thinking up questions to which we do not have answers (Brecht, 1966). Working from this principle, rather than trying to formulate solutions to the problems of our field, my contribution here is based on questions in media audience research to which I, at least, do not have the answers, as a way of taking stock of what exactly it is that we think we now know about the field.
\end{abstract}

Keywords: Audience Research; Methodology; Cultural Studies.

Resumo: Como o seu título insinua, este artigo explora diversas perguntas não respondidas, assim como questões em aberto, ligadas à pesquisa contemporânea de audiência. Estas incluem: modelos da "audiência ativa"; questões de poder cultural; mídia global e audiência transnacional; metodologia em pesquisa de audiência; problemas de essencialismo na conceituação de categorias dos membros da audiência; os pontos fortes e as limitações do modelo de codificação/ decodificação; modelos de progresso intelectual no campo; as novas mídias e tecnologias "inovadoras". Meu título deriva das "Anedotas do Sr Keuner" de Bertold Brecht, na qual ele exorta as virtudes de refletir sobre as perguntas para as quais nós não temos respostas (Brecht, 1966). Trabalhando a partir deste princípio, ao invés de tentar formular soluções para o nosso campo, minha contribuição aqui é baseada em perguntas ligadas à pesquisa de audiência midiática para as quais, eu, pelo menos, não tenho as respostas, como uma maneira de investigar o que exatamente nós sabemos sobre o nosso campo.

Palavras-chave: Estudos de Recepção; Metodologia; Estudos Culturais.

\footnotetext{
${ }^{1}$ Professor de Comunicação do departamento de Mídia e Comunicação do Goldsmiths College, na Universidade de Londres. Entre suas publicações mais recentes, destacam-se os livros Television audiences and cultural studies (1992) e Home territories (2000) e a coletânea Media and cultural theory (2006), organizada em parceria com James Curran.
} 
My title derives from Bertolt Brecht`s `Anecdotes of Mr Keuner`in which he extols the virtue of thinking up questions to which we do not have answers (Brecht 1982). Working from this principle, rather than trying to formulate solutions to the problems of our field, my contribution here is based on questions in media audience research to which I, at least, do not have the answers, as a way of taking stock of what exactly it is that we think we now know about the field.

\section{Active audiences, cultural consumption and media power}

My point of departure is with an anecdote told by the Latin American media scholar, Jesus Martin-Barbero, concerning an occasion twenty years ago now, in 1984, involving a disconcerting experience, when he took a group of his students to see a popular melodrama in a cinema in Cali, in Columbia:

'After 20 minutes of the screening we were so bored, because the film was so sentimental and corny that we started to laugh about it. People surrounding us - the cinema was full mostly of men, it was a very successful film, that's why we went - got angry and offended, so they yelled at us and tried to force us out of the venue. During the film I observed these men, moved to tears, watching the drama with a fantastic pleasure...As we came out from there, I was puzzled, wondering what the relationship was between the film I had watched and the [very different] one these men [seemed to have] watched . I had to ask myself - what was it then that I was not seeing? And what use could these men make of my ideological reading of the film, if that was not the film they saw?' (MartinBarbero, quoted in Mattelart and Mattelart 1984)

When I hear again today the repeated patrician complaint (from the Left every bit as much as from the Right) that the media are 'dumbing (us) down' because the audience is supposedly so 'hooked' on Reality TV shows that they have lost interest in serious documentary - I do wonder if we have really advanced so very far beyond Martin-Barbero's expression of honest puzzlement. In which case the question with which Martin-Barbero concludes his story remains every bit as pertinent today as it was in 1984, when he says that 'these kind of questions lead me today to face the unavoidable need to read mass culture from another place; from 
where another questions arises - what, in mass culture responds not to the logic of capital, but to other logics?' (Martin-Barbero op cit).

The taken-for-granted wisdom of our field has certainly gone through significant changes in the last twenty years. If the 1980 s and 1990 s saw a veritable boom in the production of audience ethnographies which attempted to explore the various 'other logics' of cultural consumption to which Martin-Barbero refers, today we face a new backlash, in which this work is denounced as 'pointless populism' (Seaman 1992). In this 'new' story (which seems to me to be in fact, more of a return to a very old story about media effects and largely readable as the return of a narrowly fundamentalist political economy) it is now sometimes argued that this work on the varieties and complexities of media consumption has simply led us up a blind alley - with John Fiske usually cast as the evil 'Pied Piper' who led us astray. I have outlined my own considerable disagreements of emphasis with Fiske elsewhere (Morley 1992), but to dismiss this work out of hand, as some seem now to want to do, and to reject all the insights gained by subsequent ethnographic work on the contradictions involved in media consumption, would be to return to the presumptious idiocies of the political fundamentalism which Martin-Barbero rightly recognised as itself bankrupt in 1984. It is one thing to argue (as I have myself done) that some recent audience work has exaggerated, and wrongly romanticised the supposed power and freedoms of media consumers, imagining that all audiences everywhere are engaged in a continuous form of 'semiological guerrilla warfare` (Eco 1972) with the media, in which they constantly produce oppositional readings of its products. However, it is quite another thing to imagine that there is anything to be gained by returning to simple - minded models of media power which fail to grasp Fiske's entirely correct argument that, in crossing over into the popular, any ideology pays a price for its hegemonic reach - in so far as, in the very process of becoming popular, it is inevitably 'made over' into something other than its propagators intended. To eschew this insight is to fall back into the politics of 'false consciousness', where the realm of the popular media is simply conceived as a world of 'bread and circuses' got up by the powerful to dupe the vulnerable masses - though of course, it is presumed to only affect those Others (children, women, the poor, the 
working class, the uneducated) outside the realms of adult maturity and transcendent consciousness happily inhabited by the critic Himself.

The backlash against cultural studies' supposed populism which is now emerging, in the UK at least, also has a significantly gendered dimension. This critique, articulated by people like my colleague at Goldsmiths, James Curran (1990 and 2005), but also by John Corner (1991), Greg Philo and David Miller (1997) holds cultural studies to blame for the abandonment of 'real' political questions, about power. In their place, according to these commentators, cultural studies now focuses on `inconsequential `questions about the niceties of domestic media consumption a process in which, according to Philo and Miller, we end up treating 'TV as if it were no more significant than a kitchen Toaster '(Philo and Miller op cit : 13). The problem here, as Ann Gray (1998) has put it, is that this critique depends on a thoroughly masculinist equation of the realms of 'serious` television - such as news and current affairs - with what she wittily calls the 'gender of the real ' - an equation which can only be allowed to stand if we are to abandon the 30 years of feminist theory - such as the work of Nancy Fraser and others on the gendering of the public sphere - of which these authors seem to be quite unaware (cf. Fraser 1989; Butler and Scott 1992).

Some of this may perhaps be specific to debates in the UK, but there do seem to be some parallels between this work and Daniel Dayan`s recent critique (2001) of whether the television audience is 'really`a ‘public`. Dayan's presumption seems to be that, if it is not, then it is inconsequential. The problem here is that the whole argument is premised on a very restricted sense of what 'politics` is - which quite ignores the crucial role of the media in the construction of what we might call 'cultural citizenship `` The further question raised by the critics of cultural studies audience work is whether it matters if people make oppositional or subversive decodings of media material, unless they then go out and 'do something' (go on a

\footnotetext{
${ }^{2}$ The fact that in the published version of his commentary on these matters (2001), which was in part occasioned by a conference paper of mine, to which he was responding, Dayan takes me to have assented to his formulation, is a matter of some puzzlement to me. His misinterpretation of the significance of the Nationwide Audience research in this respect seems to be founded on the erroneous assumption that, in that study, it was only members of trade unions (who equate more closely to his restricted definition of a 'public') who proved capable of producing oppositional readings of the programme.
} 
demonstration; start a petition) about it. However, the reverse question would be to ask where such critics imagine that the impetus for political change comes from, if not from many micro instances of 'pre-political attitude change in the cultural sphere - moments in which 'negotiated' or subversive forms of media consumption may often have a vital role to play. This, I take it, is precisely the issue which Peter Dahlgren's work is intended to address, in his analysis of the discursive construction of the political, the non-political and the pre/para-political (Dahlgren 2003 - this work was presented at the 'Actualites des recherches en sociologie de la reception et les publics' conference held at the University of Versailles/ Saint Quentin in October 2003 - hereafter referred to as the ARSRP conference).

As for the question of treating TV 'like a kitchen toaster` - far from being prepared to regard that as an 'inconsequential` issue, I would argue that the work of scholars like Lynn Spigel (1992 and 2001a) on the detailed history of how the domestic sphere has been reorganised to accommodate a whole series of new media technologies - and the question of how those technologies themselves have played an important part in the redesign of the domestic context of media consumption remains one of the most critical areas for further research. Naturally, in the new era of the mobile phone and the fully wired 'smart home', the familiar story of the domestication of the media will have to be complemented by the new narrative of their de-domestication - but to regard this whole arena as somehow 'non-political' seems a very gendered miscalculation (cf Morley 2003).

\section{Global media power and transnational audiences}

Certainly, in the bleak geo-political landscape in which we now find ourselves, there is plenty of cause for despair. In a world where there is little to choose between the neo-conservative fundamentalism of the Bush regime in the USA, and the market-liberal governments of the UK and other parts of Europe which are its handmaidens we see all around us a variety of increasingly direct attacks on what little remains of the autonomy of the media. However, shameless as these are, there is little to be gained by falling back into the shibboleths of a corresponding leftist fundamentalism. 
What is needed here is not to swing, in our despair, from a romanticised vision of audience 'empowerment' back to an unreconstructed politics of media manipulation, but rather, as Clifford Geertz once put it, to vex each other with ever greater precision in attempting to clarify the issues at stake.

Let us take the question of globalisation, and its relation to previous discourses of media or cultural imperialism as one key site on which to explore these issues.

Of course, we all know that simple minded theories of North American cultural imperialism, as articulated originally by Herbert Schiller (1969) and others are inadequate - not least because they were premised on an inadequate hypodermic model of media effects on their international audiences. Years of now canonical research in our field (Ang 1984; Liebes and Katz 1991; Michaels 1994; Gripsrud 1995) has shown that things do not work so simply as that and it is not just a question of an unopposed 'one-way' cultural flow form Hollywood outwards to the various 'peripheries' of the world. Nowadays, as my colleagues at Goldsmiths Kevin Robins and Asu Aksoy (2001) claim, it is transnational culture which is, in Raymond Williams` phrase, `ordinary`. In line with my argument above, derived from Fiske, about the 'price' that powerful ideologies pay for their hegemonic reach, that 'ordinariness' is a very complex phenomenon, not easily reducible to any simple arithmetic of metropolitan power. Nonetheless, we must take very seriously the evidence emerging in the Middle East about the important role of media PR in the current 'Project for the New American Century' now installed at the centre of American foreign policy by the 'neo-conservatives' in the White House - including the importance of American government-funded propaganda channels such as alHurra, even if, again, its viewers do not always consume and interpret it in the ways that the US government would wish. To put it simply, the fact that Schiller may have been wrong about how audiences consume media does not mean that he was wrong about everything else as well (cf Morley 1994 and 2005).

We might also consider here the question of 'glocalisation' which is again not really addressed by fundamentalist theories of media imperialism. It is many years now since Coca Cola declared that it was `not a multinational but a multilocal `. Any simple story of the world-wide distribution of standardised cultural goods clearly 
is not going to be all that much help to us - as we also see by considering the speed with which MTV Europe realised that it had to 'regionalise` its services, in order to succeed in attracting audiences in different parts of Europe, rather than just pumping out one standardised cultural product .However, against this argument, it can perfectly well still be asserted that, in the end, all the different versions of programmes such as Who Wants to be a Millionaire which now exist in different parts of the globe are just that - versions which ultimately, are all still derived from an Anglo-American template. This is the continuing pertinence of Jeremy Tunstall's (1977) argument that it is often the export of formats, rather than programmes, which is the key issue in matters of cultural imperialism

Where does all this leave us in relation to models of the 'active audience '? We are certainly now all aware of the many examples which the research referred to earlier has unearthed about how world-wide audiences often re-interpret 'foreign ` media materials according to local cultural grids, and that remains a crucial insight. However, there is no good reason why this should lead us to neglect the fact that, on the whole, it is still mainly North American programmes that people are busily 'reinterpreting `. We should remember that these models of audience activity were not initially designed (however they may have sometimes been subsequently deployed) to make us forget the question of media power, but rather to be able to conceptualise it in more complex and adequate ways.

\section{Questions of methodology}

A further problem here derives from the fact that most of the influential audience work of recent years has been qualitative and ethnographic in its approach. This work has certainly been the source of a whole range of insights into the complexities of how audiences 'indigenise' the media materials which they consume. However, there is a serious methodological problem about how much we should, in fact, generalise about world-wide decoding practices from the particular ethnographic examples generated by work such as Eric Michaels` (op cit) exemplary analysis of Australian Aboriginal decodings of Dallas. This work has understandably, been widely quoted in the field, but there is no intellectual warrant for presuming that just because a particular group of Australian Aboriginals produce striking re- 
interpretations of Dallas' storyline, when they read it through their own local understandings of kinship relations, that all other audiences elsewhere are necessarily engaged in such creative and transformative practices. Ethnography is a fine thing, but it always runs the danger of descending into anecdotalism and we should not mistake the vividness of the examples it offers us for their general applicability. Indeed the process of extrapolation from ethnographic examples is one that always needs to be handled with particular care.

In the long wake of the 'crisis of representation `imported into cultural studies from anthropology, after the impact of Clifford and Marcus ` (1986) work, many scholars in the field seem now to assume that self-reflexive forms of ethnographic work are the only ethically acceptable and intellectually justifiable forms of research . But, while for some purposes, ethnography is an excellent thing for others, it is simply not suitable. I would want to argue here for a greater pragmatism in our methodological choices - which requires an awareness of the `opportunity costs` of any method, ethnography included. For some purposes only statistics will help - and to my mind it is a real puzzle as to why so few people ever use numbers in contemporary audience research - despite the cogent arguments in favour of doing so advanced in recent years by Justin Lewis (1997) Darnell Hunt (1997) and Sujeong Kim (2004). There is also a particular irony, and one that will perhaps be particularly resonant in France, that Anglo-American cultural studies scholars, who themselves would never resort to the use of numbers in their own research, nonetheless often quote work by Bourdieu (1984) which was, of course, founded on the use of sophisticated statistical methods. Conversely, I remain puzzled as to why so many cultural studies scholars, in designing their research, assume that more contextual information is always a Good Thing. As one who has had the unhappy experience of being involved in at least one research project which simply 'died ' under the weight of the quantity of unanalysed contextual data that had been collected, I am very aware that too much context can sometimes be a highly dangerous thing. None of this is intended to undermine the value of ethnographic research, but simply to register that now that the intellectual argument about its legitimacy as an approach has been won, it may be time to recognise, as Andy 
Ruddock does in his recent survey of the field, that other, more traditional methods may still serve us better on some occasions (Ruddock 2001).

\section{The problem of 'Essentialism' in audience studies}

Nowadays it is widely taken for granted that any form of 'essentialism', which reduces individuals to the status of mere members of a social category (of class or gender or race) is a great danger in audience studies. Regretfully, my own early study of the Nationwide Audience (Morley 1980; Morley and Brunsdon 1999) which is largely known at second hand, through the many summaries of it which exist in textbooks in the field, seems to have played an unwitting part in installing this particular orthodoxy. The taken-for-granted wisdom here, retailed in most of these summaries, and faithfully reproduced in student essays, is that the Nationwide research showed us all that it was hopeless to imagine that audience decodings of the media were structured by class - and that to do so was to engage in 'class essentialism '- because it is, in fact, all so much more complicated than that.

The best-known statement of this position is probably that offered by Graeme Turner in his widely read history of British cultural studies (1990). In his account of the Nationwide research, Turner concludes that the attempt there to 'tie differentiated readings to gross social and class determinants was a failure' and indeed that, as matter of principle, the very attempt to make empirical connections between social position and modalities of media consumption is 'a waste of time' (Turner op cit 132-3).

The first problem here, as I have argued before (Morley 1992) is that the thesis that decodings are straightforwardly determined by class was simply not the proposition which the Nationwide project set out to explore . Harold Rosen's (1972) critique of Basil Bernstein's (1971) theory of the relations of class and linguistic form, for making this overly determinist error, had in fact been foundational to the original design of the Nationwide project (cf Morley 1974). The question that project set out to explore was how decodings are influenced and structured by social position, in an overdetermined manner, across a range of dimensions - of class, 'race`, ethnicity and gender - not class alone. Moreover, new work which re-analyses the Nationwide data, done by Sujeong Kim (op cit), using computerised forms of statistical analysis 
which were unavailable to me in 1979 , shows that, in fact, the decodings of the groups in that project were, once one allows for the combined influence of these various factors, actually more structured by social position than I originally claimed.

Kim's reanalysis of my data, in which she carefully distinguishes (in ways I was unable to do) between readings of individual programme items and responses to the programme as a whole, and further distinguishes between the separate determining effects of class, ethnic, racial, gendered and generational identities, opens up, in my view a valuable way forward for further research in this field. The recent swing away from theories of social determination, towards the now widely held presumption of the 'undecidability' of these influences, has thus given rise to what may be among the most pernicious of the myths which have come to dominate our field. Certainly, as the work of Andrea Press (2003) and Lynn Thomas (2003) shows us, despite the claims of much post-structuralist theory, class is still very much with us, if in new and always changing forms.

Curiously, at the same time that the invocation of class forms of determination of decoding has increasingly been dismissed, in much of the recent work which explores the decoding of media materials in relation to 'race' and ethnicity, the explanatory framework has sometimes tended towards a rather essentialist position. In this shift 'race' or ethnicity replaces class, to become the new master category of analysis and individual audience members' decodings of media material are 'explained' by reference to their membership of racial or ethnic categories. This is the force of Ramaswami Harindrath's (2003) critique of Tamar Liebes and Elihu Katz's now canonical study of cross-cultural readings of Dallas - in so far as Liebes and Katz (1991) effectively 'reduce' their respondents to their ethnic identities. Evidently, the more interesting work in this sub-field - such as Marie Gillespie's analysis of British Asian forms of cultural consumption Gillespie (1995), Darnell Hunt`s work on Black decodings of coverage of `race` issues on US television ( op cit) or Kevin Robins and Asu Aksoy`s (op cit) work on media consumption among Turkish migrants in Europe - is that which takes the question of 'race` and ethnicity as only one of a number of factors in play. This work does not reduce members of ethnic groups to their racialised identities, but recognises the varying ways in which the media are used in the construction of identities and the 
ambivalence which people feel towards the categories of ethnic 'belonging' to which others often assign them (cf Bauman 1996).

In some recent audience work, we also see another interesting move where, rather than exploring the question of how decodings may be explained by reference to matters of cultural identity, scholars have begun to explore how, simultaneously, people use media materials in the construction of the very 'identities` which are sometimes held to explain their decoding practices. In this connection one might point to the work of David Buckingham, Sara Bragg and Rebekah Willett (all 2003) which explores the 'performative' dimension of identities. In this context, Valerie Walkerdine and Lisa Blackman (2001) argue that not only does the question of the construction (and destabilisation or maintenance) of identities logically precede the question of specific moments of decoding, but that we make a mistake if we continue to prioritise the cognitive and rational dimension of media consumption over the emotional and the affective. This they rightly argue, remains one of the limitations of the Encoding/Decoding model, which still today casts such a long shadow over the study of media audiences. Let us turn now to that model, directly - enshrined as it is, by Elihu Katz and his colleagues, in their recent book, as one of the 12 'canonical texts' of media research (see Gurevitch and Scannell, in Katz et al, eds 2003).

\section{The 'Encoding/Decoding' model revisited again}

It is perhaps worth considering where we now stand in relation to the key conceptual components of that model, for important uncertainties remain - not least in relation to Hall's central category of the 'preferred reading'. Many commentators continue to avoid the central issue of whether this is a property of the text, of the analyst 's imagination, or a form of prediction of audience behaviour which is empirically falsifiable. Certainly, few seem to have noted Hall`s own militant, position, which he expounds in his retrospective interview with Justin Lewis and Jon Cruz, where he insists that the 'preferred reading' is undoubtedly a property of the text - which can (and indeed, must) be identified by careful analysis of the text itself 
(Hall 1994). If Hall is right, then textual analysis still has a much more important place in audience work than many subsequent scholars have recognised3.

However, if we cannot abandon the question of textual analysis by dissolving the text into its readings or contextual uses, the question still remains as to the nature of the text that we should analyse. At one time, under the influence of structuralist theories of language and meaning (de Saussure 1974; Hall 1981) it seemed obvious that content analysis could be of little help, because of the way in which it disaggregates texts into their atomised constituent parts and pays no attention to the structure of their relations - which, according to structuralism is, of course, what gives them their meanings. However, we now know, from many studies of viewing practices, that people, on the whole do not actually consume whole texts on television (even if they still do in the cinema). Rather, in the age of the remote control device, they watch cannibalised schedules of their own construction, as they jump from one bit of programming to another - in which case, the structural relations within any one programme will be irrelevant, except in that particular sub-category of viewing in which people do sit down and watch the whole of their favourite programmes. In that case, we may need to abandon the presumption that in their work on cultivation theory, George Gerbner and his colleagues were misguided in focussing on overall patterns of programme 'flow' and recurring imagery, rather than on individual programme texts. To that extent it may now prove useful to go back to forms of analysis that concern themselves with the accumulative meaning of a variety of 'bits' of programming, rather than with the analysis of single texts (see Gerbner 1970; see also Ruddock op cit for a sympathetic recent reconsideration of this field of work)

A further, fundamental problem about matters of interpretation is raised by Condit (1989) and Caragee (1990) who both argue that many audience scholars have exaggerated the extent of the polysemy of meanings of media texts and ignored the limits placed by texts themselves on the process of interpretation. Their argument that most texts have meanings which are perfectly clear to the majority of their

\footnotetext{
3 The Nationwide Audience work itself was premised on a detailed analysis of the programme shown to audience groups which was published as Everyday TV:Nationwide (Brunsdon and Morley 1979). See also Brunsdon (1989) on the continuing importance of textual analysis. A good instance of the value of combining textual analysis with audience work in this way was provided at the ARSRP conference by Darren Waldron, 2003).
} 
readers - who only differ in their evaluation of them, takes us back to another unresolved issue raised long ago by John Corner (1981). This concerns the need to disentangle the elements of comprehension and evaluation - which are intertwined in the Encoding/Decoding model. This takes into deep water, as Hall`s original (1973) argument was that, in any society characterised by significant cultural divisions, and thus a 'systematically distorted`system of communication (Habermas 1970) the elements of comprehension and evaluation will inevitably be intertwined - with some kinds of interpretations dismissed by more powerful others as merely 'misunderstandings`. The unresolved difficulty here is that the price of analytical clarity, if we attempt to too neatly divide matters of interpretation and evaluation, may be to disassemble the empirical conjunction of these issues and thus to evacuate from the model the very questions of cultural power which it was designed to address (cf Hall 1973).

Yet further important questions remain about the status of another of the model's central categories - that of the `oppositional reading `. It may well be that the original model, in its search for overtly political forms of opposition to the culturally dominant order, overvalues 'oppositional' rather than 'negotiated' decodings. Moreover, it is by no means clear that an audience's refusal to even engage with a text sufficiently to make any decoding of it - on the grounds of its irrelevance to their concerns (which is the position of many people in the UK, in relation to much of contemporary news and current affairs programming) is less of an oppositional reading than one which is at least sufficiently engaged by a text to bother to 'disagree ' with it. As Dominique Pasquier (2003) argues, the 'indifferent audience' may be one of the key issues for contemporary audience research. This is also the significance of the varieties of 'disengaged' or 'ironic' audience responses to media materials reported in the work of Dominique Cardon and Jean-Phillipe Huertin (2003). Conversely, it would also be useful to clarify the significance of the many the examples of 'over-invested' (or perhaps 'super-dominant') readings of the consumerist ideology of programmes like Dallas and Dynasty made by people in Poland and Romania in the late 1980s, which (contextually) functioned as oppositional to and subversive of the dominant political cultures of Eastern Europe at that time. 
All of this is to suggest that there are serious problems still to be resolved in developing the original insights generated by the Encoding/Decoding modeI - but it is also to recognise that the model, despite its limitations, still has much to offer. Unsurprisingly perhaps, as one much involved in the development of that model I am unpersuaded by the accounts of its demise offered by David Buckingham (1999) and Martin Barker (2003). Nicholas Abercrombie and Brian Longhurst (1998) similarly argue that the 'Incorporation/ Resistance Paradigm' (as they re-name the encoding/decoding model) should now been superceded by what they call the 'Spectacle/ Performance Paradigm'. This latter case is particularly puzzling, as not so very long ago, the first of these two authors could be found, in his denunciation of what he called the 'Dominant Ideology Thesis', arguing that media power was of little importance in the maintenance of social order - and thus that media studies as a whole (and audience research in particular) was a rather inconsequential field, by comparison to serious matters of sociological enquiry (Abercrombie et al 1984). To denounce a field of research is one thing, but it is a rather curious intellectual manouvre to then move into it and announce the triumph of one's own version of it. Moreover, Abercrombie and Longhurst's intellectual schema, in which one model of media-audience relations is seen to displace another, in a steady form of intellectual progress, displays a worrying form of 'stagism' in its argument. It may well be that, rather than look to a schema of this kind, in which we pass ever onwards, from one singular truth to another, we should see that each of these models captures - or highlights - a different dimension of media-audience relations. What we perhaps need here is a multi-dimensional model which incorporates insights along all of these dimensions. The Encoding/Decoding model may well have over-valued the explicitly political dimension of the media's relation to their audience - but to now announce that these relations should now be understood without effective relation to the political seems an odd conclusion to draw.

\section{Models of Intellectual Progress}

Intellectual progress is, of course, a fine and marvellous thing, for which we must all strive, but I sometimes wonder whether in these respects our field is in danger of 'mistaking paradise for that home across the road' as Bob Dylan once put it in a philosophical moment. Of course, it could just be that, nowadays, I find myself 
less enamoured by neophilia, and sometimes on the other side of debates about intellectual parricide than I might have been at an earlier stage in my career. The first warning signs, for me, of trouble here, were when I started going to conferences in the 1990 s at which the mere mention of John Fiske`s name raised a smile, if not a laugh. As I noted earlier, I have all kinds of disagreements with Fiske myself, but the one thing I do not think we should do is to airily dismiss previous work as if we all, obviously, 'know better' than that now. That way lies hubris4. I also worry when I read claims such as that made, implicitly at least, by Pertti Alasuutari, that we now see a `New Generation ` of audience work, which will boldly go where none have been before (Alasuutari 1998). This simply seems to me to be a bad model of how intellectual progress operates - by the discarding of the old in favour of the new. Alasuutari argues that what should distinguish the new approach to audiences is its focus on practices of viewing, rather than on individual moments of decoding or interpretation of texts. It is not that I think that attention to viewing practices is a bad idea in itself - indeed, here I would agree with Eric Maigret (2003) when he argues that we need to attend to more than the immediate ' $R$ ' moment in reception studies and consider the role of the media in everyday life (here Maigret's comments parallel the suggestions made in Janice Radway's (1988) argument). However, what is involved here, surely, is the addition of that broader perspective, which nonetheless maintains attention to specific moments of decoding, rather than the wholesale abandonment of the one approach in favour of the other. One can certainly argue that we need to add the analysis of the 'horizontal analysis of modes of participation in media consumption to the more familiar analysis of the 'vertical 'dimension of the transmission of ideologies and power, but this is surely not a case where the one truth replaces the other. It is rather a question of developing a bi-focal mode of vision, in so far as we need both close up/micro perspectives and long-sighted/ macro ones, for different purposes, and at different moments - but neither perspective reveals the whole truth.

It perhaps also remains for me to comment on Martin Barker's (2003) commentary on the problems with the Encoding/Decoding model. While he and I

\footnotetext{
4 In this respect, I regard the plans of the new Journal of Audience and Reception Studies, edited by Martin Barker, to reprint older work from now neglected perspectives in our field to be exemplary of the best intellectual practice)
} 
evidently agree in our assessment of Abercrombie and Longhurst's intervention which he wryly describes as offering a kind of Hegelian teleology of intellectual progress in the field of audience studies, with themselves as its saviours - and while I am fully in sympathy with many of his particular suggestions for future work in the field, I find myself unable to assent to his own dismissive assessment of Hall's model. Indeed, he goes beyond saying that the Encoding/Decoding model has nothing left to offer, to argue that it has positively 'hindered and indeed harmed our phase of audience work quite substantially' (Barker op cit, Note 8). Most particularly Barker accuses Hall - and the subsequent audience research which he influenced - of taking a kind of intellectual 'scorched earth' strategy, in so far as he claims that those working in this new tradition insisted on dismissing all previous work and 'starting all over again from scratch' (a parallel argument to Curran's (1990) critique of what he called the 'new revisionism' in audience research). This I find hard to credit, as can be seen, not least, by consulting the original (1973) version of Hall's paper, which is very clear about the extent to which his critique is advancing precisely through a critical dialogue with the 'uses and gratifications' perspective developed earlier at the Leicester Centre for mass communications (see Halloran 1970). As I have argued elsewhere, this has always been Hall's way, committed as he is to a form of productive eclecticism in intellectual life, as a mode of 'selective, syncretic inclusiveness in which one attempts to take what is best from various intellectual traditions and work with those elements towards new syntheses' (Morley 1997 : 303). As for the supposed dismissal of 'uses and gratifications' in the cultural studies tradition, my own Family Television study (1986:15) declares, early in its first chapter that, in it, I 'have attempted to build upon some of the insights of the uses and gratifications approach'.

Even more curiously, it seems to me, as his argument develops, Barker in fact goes on to commit the very intellectual error of which he accuses the cultural studies tradition which follows Hall, when he dismisses the Encoding/Decoding work as leading us up a blind alley and urges us to begin again from elsewhere. To this extent, I find the assessment of the Encoding/Decoding model offered by Michael Gurevitch and Paddy Scannell (op cit) more persuasive, when they recognise that Hall's model has belatedly had 'canonicity' thrust upon it, and always was intended as no more than a 'working model', designed from the start for further development (cf 
Hall's own comments on this, on pp 245-6 of Hall 1994). In this context, Gurevitch and Scannell rightly argue that the value of the model is to be judged not simply in its own terms, but with reference to the subsequent body of work which it has spawned and enabled, as a seminal rather than canonic text. Here, in effect, their argument echoes the terms of Harold Bloom's analysis of the great texts of the literary tradition, which are to be judged, for Bloom (1994), in terms of his theory of the 'anxiety of influence'. If Bloom seems an odd figure to whom to turn in this context, given his visceral dislike of the 'Birmingham (England) school of cultural materialism' (Bloom op cit 518), I would argue that his own declared political prejudices should by no means debar us from recognising the acuity of his own analysis of how intellectual influence works, not only in literature, but also in other fields of scholarship. For Bloom, a great writer is not necessarily one who creates 'ex nihilo' but rather, one who acutely judges which past work continues to be of value - crucially what cannot be cast aside - and thus returns to the key questions and issues set by that previous tradition, to rework them into something which is still new for their own times. This is no simple matter of intellectual agreement - to take but one example, as Bloom says in his discussion of the poetic tradition, while 'Crane's relation to Eliot was almost wholly antithetical' and while he 'rejected Eliot's vision' he 'could not evade Eliot's idiom' - because Crane recognised that Eliot's idiom had what Bloom calls the 'power of contamination' on the best of the later writers - which, for him is no negative quality, but precisely, the 'pragmatic test for canon formation' (op cit 523). Much as the particular content and political trajectory of Hall's work would appal Bloom, the Encoding/Decoding model clearly passes that test, and to now dismiss it out of hand - rather than to go on working with its best elements, to try to deliver new insights would, in my own view, be foolhardy.

\section{Technologies of 'newness'}

The reader may have noted that, in one of my earlier examples, when I referred to the age of the TV remote control as defining a particular and distinctive regime or mode of media consumption, that I smuggled a bit of technological determinism into my argument. There are several problems buried here. I certainly do not want to fall back into a simplistic mode of technological determinism - the dangers of which, are particularly pertinent in relation the 'new media' discussed 
below. However, as Martin Lister and his colleagues have recently argued, it might be time to reconsider whether Raymond Williams did, in fact, satisfactorily resolve that matter in Television, Technology and Cultural Form (Lister et al 2003; Williams 1974). It is certainly the case that many cultural studies scholars behave as if Williams did in fact, resolve the problem of technological determinism on a once and for all basis. However, as Lister et al claim, different technological eras may have different characteristics in this respect, and we may need to consider these issues anew in that context (cf Morley forthcoming). The same applies to Williams' now also canonical definition of 'flow` as the essence of television (also Williams 1974) which, as Mimi White has recently argued, might also be due for another look, as we enter a different technological era (White 2003).This is a point which Dominique Pasquier (2003) rightly raised at the ARSRP conference, when she suggested that we need to consider audience 'reception frames' in relation to formats as much as to programmes.

It may well be that losing your TV remote control down the back of the sofa, and then having to actually get up and walk across the room to change channels on your TV is an excellent practical demonstration of how that piece of technology has changed the experience of viewing in significant ways. However, we still need to disentangle that issue from the question of whether these technologies are 'empowering` in the ways that liberal market ideologies present them as being. We should not mistake activity for power and we should recognise that the consumer's ability to choose options from within a pre-set menu is a very limited form of power, compared with that of the institutions that construct those menus.

We are endlessly being told that we need to 'go beyond 'old models of the media - and even that we should now abandon the very idea of an audience as a separable entity - as we are all, now, audiences almost all of the time, to one medium or another, in our increasingly `media saturated `environment, as Todd Gitlin (2001) puts it. Of course, this argument itself is perhaps not so new as is sometimes proposed. Some time back now, Armand Mattelart (1993) made exactly this point, in relation to the gradual process of the colonisation of public space by the commercial discourses of advertising. Nonetheless, as Anna McCarthy (2001) points out, in her 
study of the new forms of what she calls 'ambient television`, we do undoubtedly, now face a new stage in these developments.

The larger question at stake here concerns the extent to which we do need to reconceptualise all these issues in relation to the development of the 'new media'. However, we could do worse than to heed Lynn Spigel`s argument that, in fact, the first thing we need, if we are to avoid getting caught up in the futuristic hype that surrounds so many of the current technological developments, is a more developed historical perspective, which alerts us to the extent to which previous eras have themselves had to face problems of similar sorts (Spigel 2001b). For one thing, we should note James Carey`s (2000) argument that the `digital age`is perhaps best understood as beginning with the invention of the Telegraph in the 1840 s. We should also recall that the 'rhetorics of the technological sublime` that now surround the new computerised media, similarly accompanied the invention of the 'Victorian Internet ', as Tom Standage (1999) describes the international telegraph system. The telegraph, in its own time, was thought by some to be the harbinger of an era of world peace, rather in the manner of some current predictions about the democratic potential of cybercommunications.

Today we also see a curious development, whereby many universities are setting up well-resourced departments of 'new media' - which march to a quite different drumbeat than do those of us involved in the study of what (presumably) must now be the `old media `. The new media scholars are rapidly setting up a whole new orthodoxy, which argues that old-fashioned media studies has little to offer any more. Influential scholars like William Mitchell (1994), Friedrich Kittler (1999) and my Goldsmiths colleague Scott Lash (2002) now argue that media studies has simply got it all wrong over the last twenty years - and that, to understand the new media, we should return to the wisdom of Medium Theory - as espoused by Marshal McLuhan (1964), all those years ago - as the Digital Age now supposedly demonstrates the truth of his insights. A new orthodoxy is rapidly developing here, in which a bizarre alliance of McLuhan with Deleuze and Guattari (1983 and 1987) is presented, in Anglo-American theoretical circles at least, as having produced a body of theoretical work with a kind of 'natural fit' with the logics of the new, 'non-linear' technologies. 
The problem is that so much of the binary division on which this contrast of old and new media rests is badly overdrawn. There is, as yet, little sign of the media convergence (in either the realms of production or consumption) which has been so widely trumpeted. The division between analogue and digital media remains rather blurred - and the `Great Expectations `of consumer demand for enhanced interactive media services remain, as yet largely unfulfilled. In the UK at least, not only is there little evidence of effective demand for most of these services, but in one of the paradoxes of 'technical rationality', manufacturers are increasingly worried by the evidence that many people are not only unable to use many of the ever more complex functions on the technologies in their homes, but are, indeed, put off buying new machines for precisely this reason. Moreover, even the newest technologies can be recruited to the most traditional of purposes. There are websites for the conduct of arranged marriages, mobile phone systems designed to ring the 'faithful ` to let them know when it is time for prayer - or when their football team has scored - and the most popular website in the UK is one called 'Friends Reunited', offering the thoroughly nostalgic and old-fashioned pleasures of putting old school friends back in touch with each other.

The current claims for the specificity of the realm of the interactive media can thus be seen to be woefully exaggerated. I was talking, not long ago, to a young interactive media professional, who referred, in passing, to the contrast between her world and that of the old 'slouchback' media .That very phrase clearly connotes a thoroughly negative image of the passive, morally bankrupt, corrupted audiences of 'couch potatoes' who are then presumed to have characterised that era - an assumption that we know to be false, from many years of audience research. The 'netizens ' of the world of the new media then automatically accrue a positive value, by contrast - as they are all presumed to be sitting forward (or, at least, upright) interacting significantly with the new media of their choice. Apart from anything else, the problem here is that, as we know, a lot of their activity is of a relatively trivial nature. But there is also a further irony here - notwithstanding all the hype about the interactive dimensions of these new media, at a conceptual level, most new media theory also returns us, ironically enough, to a place we started out from, long ago - to a technologically determinist version of hypodermic media effects. In this vision, 
these technologies are seen as inevitably transforming the both the world around us and our very subjectivities. It is as if the technologies themselves had the magical capacity to make us all active - or in some visions, even to make us all democratic - a strange form of media effects, indeed.

In conclusion, I can only say that it seems to me that, just like Brecht's $\mathrm{Mr}$ Keuner, we should be pleased that we have many important questions still left unanswered, which will provide meat for future debate in the field of media audience research

\section{Bibliography:}

(A number of these references are to papers presented at the conference referred to earlier on audience research, held at the University of Versailles/St Quentin in October 2003, which is referred to in this bibliography as the ARSRP conference).

Abercrombie, N. et al. The Dominant Ideology Thesis. London: Allen and Unwin, 1984.

Abercrombie, N. and Longhurst, B. Audiences: a sociological theory of performance and imagination. London: Sage, 1998.

Alasutaari, P. ed. The Inscribed Audience. London: Sage, 1998.

Ang, I. Watching Dallas. London: Methuen, 1984.

Barker, M. 'I have seen the future and it is not here yet..' Paper to ARSRP conference, 2003.

Bernstein, B. Class, Codes and Control, Vol 1 London: Paladin, 1971.

Bloom, H. The Western Canon. New York: Harcourt Brace, 1994. 
Bourdieu, P. Distinction London: Routledge, 1984.

Bragg, S. 'Boy meets Boy meets Girl meets Girl' paper to ARSRP conference, 2003.

Brecht, B. 'The Anecdotes of Mr Keuner'. in his Selected Writings London; Faber, 1982.

Brunsdon, C. 'Text and audience' in E. Seiter et al (eds). Remote Control. London: Routledge, 1989.

Brunsdon, C. and Morley, D. Everyday Television: Nationwide. London: British Film Institute, 1979.

Buckingham, D. 'Researching children's media culture' paper to conference on 'Researching Culture' University of North London September 1999.

Buckingham, D. 'Show and tell: learning about sex from TV drama' paper to ARSRP conference, 2003.

Butler, J. and Scott J.W. eds. Feminists Theorise the Political. London: Routledge, 1992.

Carragee, K. 'Interpretive media study'. Critical Studies in Mass Communication Vol 7.2, 1990.

Cardon, D. and Huertin, J-P. 'Attractions-Scaterrings: mobile receptions of the Telethon' paper to ARSRP conference, 2003.

Carey, J. Interview with James Carey in How the Victorians Wired the World Channel Four TV programme, transmitted 8/7/2000.

Clifford, J. and Marcus, G. eds. Writing Culture. Berkeley: University of California Press, 1986.

Condit, C. 'The rhetorical limits of polysemy'. Critical studies in Mass Comunication. Vol 6.2, 1989.

Corner, J. 'The Nationwide Audience'. Media, Culture and Society Vol 3.2, 1981.

Corner, J. 'Meaning, genre and context' in J Curran and M Gurevitch (eds). Mass Media and Society. London: Edward Arnold, 1991.

Curran, J. 'The 'new revisionism' in mass communication research'. European Journal of Communications. Vol 5(2-3), 1990.

Curran, J. 'Media and cultural theory in the age of market liberalism' in J. Curran and D. Morley (eds) Media and Cultural Theory. London: Routledge, 2005.

Dahlgren, P. 'Reception, rejection and interactivity: political navigation of the media deluge among young citizens' paper to ARSRP conference, 2003.

Dayan, D. 'The peculiar public of television'. Media, Culture and Society Vol. 23.6, 2001.

Deleuze, G. and Guattari, F. Anti-Oedipus Minneapolis: University of Minnesota Press, 1983.

Deleuze, G. and Guattari, F. A Thousand Plateaus. Minneapolis: University of Minnesota Press, 1987. 
Eco, U. 'Towards a semiotic enquiry into the TV message'. Working Papers in Cultural Studies No. 3, 1972.

Fraser, N. Unruly Practices: Power, Discourse and Gender in Contemporary Social Theory. Minneapolis: University of Minnesota Press, 1989.

Gerbner, G. 'Cultural indicators'._Annals of the American Academy of Political Social Science No 388, 1970.

Gillespie, M. Television, Ethnicity and Cultural Change. London: Routledge, 1995.

Gitlin, T. Media Unlimited. New York: Metropolitan Books, 2001.

Gray, A. 'Audience and reception research in retrospect' in P. Alasutaari (ed). The Inscribed Audience. London; Sage, 1998.

Gripsrud, J. The Dynasty Years. London: Routedge, 1995.

Gurevitch, M. and Scannell, P. 'Canonisation Achieved? Stuart Hall's Encoding/Decoding' in E. Katz et al (eds). Canonic Texts in Media Research. Cambridge: Polity Press, 2003.

Habermas, J. 'Systematically Distorted Communication' in H.P. Drietzel (ed). Recent Sociology. Vol 2 London: Collier-Macmillan, 1970.

Hall, S. 'Encoding and Decoding in the Television Discourse'. Centre for Contemporary Cultural Studies, Stencilled Papers No. 7, 1973.

Hall, S. 'Encoding/Decoding' in S. Hall et al (eds). Culture, Media, Language

London: Hutchinson, 1981.

Hall, S. 'Interview with Stuart Hall' in J. Cruz and J. Lewis (eds). Viewing, Reading, Listening Boulder, Colorado: Westview Press, 1994.

Halloran, J. The Effects of Television. London: Panther Books, 1970.

Harindrath, R. 'Reviving cultural imperialism' in L. Parks and S. Kumar (eds). Planet $T V$ New York: New York University Press, 2003.

Hunt, D. Screening the Los Angeles Riots Cambridge: Cambridge University Press, 1997.

Kim, S. 'Re-reading David Morley's The Nationwide Audience'. Cultural Studies, Vol 18.1, 2004.

Kittler, F. Gramaphone, Film, Typewriter. Stanford: Stanford University Press, 1999.

Lewis, J. 'What counts in cultural studies'. Media, Culture and Society, Vol 19, 1997.

Lash, S. Critique of Information. London: Sage, 2002.

Liebes, T. and Katz, E. The Export of Meaning. Oxford: Oxford University Press, 1991.

Lister, M. et al New Media : A Critical Introduction. London: Routledge, 2003.

McCarthy, A. Ambient Media. Raleigh, Durham: Duke University Press, 2001.

McLuhan, M. Understanding Media. Harmondsworth: Penguin, 1964. 
Matellart, A. and Mattelart, M. Penser les Media. Paris, 1984.

Mattelart, A. Advertising International. London: Routledge, 1993.

Mitchell, W.J.T. Iconology. Chicago: University of Chicago Press, 1994.

Michaels, E. Bad Aboriginal Art and Other Essays. Minneapolis: University of Minnesota Press, 1994.

Morley, D. 'Reconceptualising the media audience'. Centre for Contemporary Cultural Studies. Stencilled Paper, 1974.

Morley, D. The Nationwide Audience. London: British Film Institute, 1980.

Morley, D. Family Television. London: Comedia, 1986.

Morley, D. Television, Audiences and Cultural Studies. London: Routedge, 1992.

Morley, D. 'Postmodernism - the highest stage of cultural imperialism?' in M. Perryman (ed) Altered States. London : Lawrence and Wishart, 1994.

Morley, D. 'Theoretical Orthodoxies' in M. Ferguson and P. Golding (eds) Cultural Studies in Question. London: Sage, 1997.

Morley, D. 'What's home got to do with it?'. European Journal of Cultural Studies, Vol 6.4, 2003.

Morley, D. 'Globalisation and cultural imperialism reconsidered' in J. Curran and D. Morley (eds) Media and Cultural Theory. London: Routledge, 2005.

Morley, D. and Brunsdon, C. 'Introduction' to The Nationwide Television Studies. London: Routledge, 1999.

Pasquier, D. 'Les measures de l'engagement' paper to ARSRP conference, 2003.

Press, A. 'Tracing the everyday nature of the digital divide' paper to ARSRP conference, 2003.

Philo, G. and Miller, D. 'Cultural compliance: dead ends of media/cultural studies and social science' Glasgow Media Group. University of Glasgow, 1997.

Radway, J. 'Reception studies' Cultural Studies, Vol. 3.2, 1988.

Robins, K. and Aksoy, A. 'From spaces of identity to mental spaces: lessons from Turkish-Cypriot cultural experiences in Britain'. Journal of Ethnic and migration Studies, Vol. 27.4, 2001.

Rosen, H. Language and Class. Bristol: Falling Wall Press, 1972.

Ruddock, A. Understanding Audiences. London: Sage, 2003.

de Saussure, F. Course in General Linguistics. London: Fontana, 1974.

Schiller, H. Mass Communication and American Empire. New York: Beacon Books, 1969.

Seaman, W. 'Active audience theory: pointless populism?' Media, Culture and Society, No 14, 1992.

Spigel, L. Make Room for TV. Chicago: Chicago University Press, 1992. 
Spigel, L. Welcome to the Dreamhouse Raleigh, Durham: Duke University Press, 2001a.

Spigel, L. 'Media Homes: then and now'. International Journal of Cultural Studies, Vol 4.4, 2001b.

Standage, T. The Victorian Internet. Boston, Mass: Phoenix Books, 1999.

Thomas, L. 'Negotiating identity in qualitative audience research: social class, gender, ethnicity' paper to ARSRP conference, 2003.

Tunstall, J. The Media are American. London: Constable, 1977.

Turner, G. British Cultural Studies. London: Unwin Hyman, 1990.

Waldron, D. 'Representations et receptions de la sexualite 'Queer' dans le cinema Francais contemporain' paper to ARSRP conference, 2003.

Walkerdine, V. and Blackman, L. Mass Hysteria. London: Edward Arnold, 2001.

White, M. 'Flows and other close encounters with TV' in L. Parks and S. Kumar (eds) Planet TV. New York : New York University Press, 2003.

Willett, R. 'Constructing the digital 'Tween': market discourse and girls' interests' paper to ARSRP conference, 2003.

Williams, R. Television, Technology and Cultural Form. London ; Fontana, 1974. 